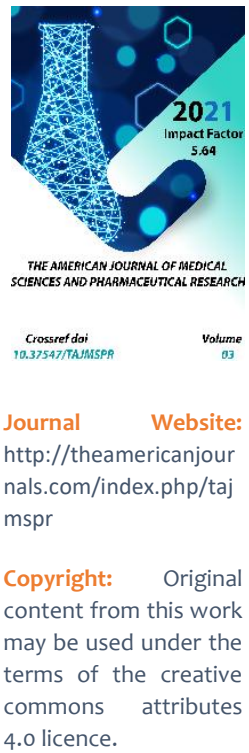

\section{Assessment Of The Consequences Of The Ozone For The Treatment Of The Soft Tissue Injuries Of The Maxillofacial} Area

\author{
Farkhod Rakhmonovich Abdurakhmonov \\ Assistant, Department of Maxillofacial Surgery, Samarkand State Medical Institute, \\ Samarkand, Uzbekistan
}

Jasur Alimdjanovich Rizayev

Doctor Of Medical Sciences, Professor, Samarkand State Medical Institute, Samarkand, Uzbekistan

\author{
Shukhrat Abdujajilovich Boymurodov \\ Doctor Of Medical Sciences, Professor, Department Of Maxillofacial Surgery, Tashkent \\ Medical Academy, Tashkent, Uzbekistan
}

\title{
ABSTRACT
}

As it is clear that wounds of the maxillofacial area are much more different from other parts of the body. Due to the importance of its function and cosmetic value combined soft tissue lesions occupy a special position in human bones and tissues. In this article certain valuable information is shown about ozone's physical, chemical compositions and its positive effect on the recovery of the combined soft tissue wounds located in the facial region. To evaluate the effectiveness of ozone for the treatment of soft tissue wounds of maxillofacial injuries overall 60 patients investigated [1,2]. As a result of this, ozone tends to be much more effective than traditional ways of treatments.

\section{KEYWORDS}

Soft tissue, wounds, wound healing, ozone, maxillofacial injuries.

\section{INTRODUCTION}

The process of healing injuries in the maxillofacial region is complicated and has its step by step difficulties. Therefore, in this case along with the environment around the wound in the organism also several changes take place. The integrity of the mucous membrane and skin is broken as the trauma occurs. In the practice of healthcare wounds of the maxillofacial region has their problems and complications along with early and late complications [3-6]. This can be continued for some periods or even could cause death. Oxygen supply is important in the wound healing process, as oxygen is not sufficient recovery of the soft tissue injuries of the maxillofacial region like another wound 
dallied. In this situation, ozone plays important role in process of wound healing and can accelerate recovery of the injured region of the maxillofacial region. Nowadays, many health professionals pay attention to ozone as it is a natural substance and has no side effect and can treat the wound of the maxillofacial region effectively [7-10]. Because ozone has anti-inflammatory, antiviral, antibacterial, immunostimulatory and antihypoxic effect.

\section{MATERIALS AND METHODS}

Overall 60 patients over the age of 17 were included for the investigation of the maxillofacial wounds healing process in the maxillofacial department of the Samarkand city's centralized hospital. To the analysis of the results, these patients were separated into 3 groups, including 2 main groups and 1 controlled group.

\section{Proportion of patients}

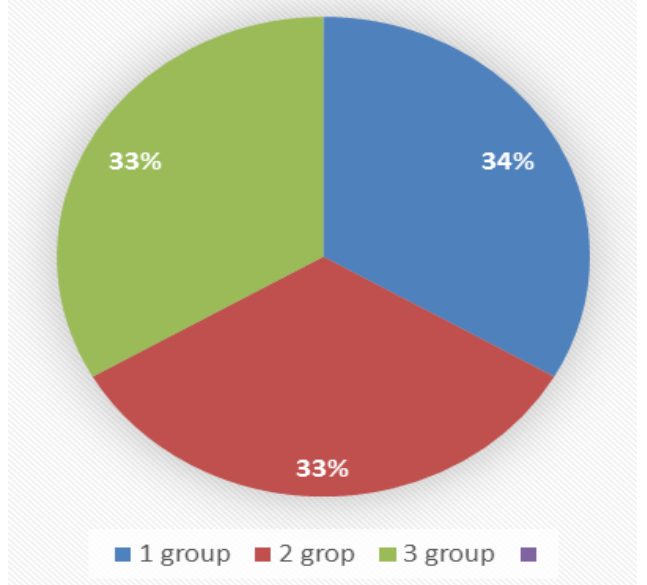

Figure.1. Methods of treatment:

1-group: Chlorhexidine bigluconate is used as a method of traditional treatment for cleaning wounds of the maxillofacial regions.

2-group: Ozonated $\mathrm{NaCe} \quad 0,9 \%$ solution administrated IV and wound surface is cleaned with chlorhexidine bigluconate.

3-group: IV drip infusion of $\mathrm{O}_{3}$ therapy and treatment of wounds with ozonized $\mathrm{NaCe}$ $0,9 \%$ solution, applications with ozonized olive oil.

Figure.1: 3 different methods of treatment of soft tissue wounds of the maxillofacial region. In the first group, 20 patients were included who received traditional chlorhexidine bigluconate for the cleaning of the soft tissue wound of the maxillofacial region.

The same number of 20 patients were in the second investigation group with ozonated norma saline solution administrated IV and the wound surface is cleaned with chlorhexidine bigluconate [12-15]. The second and third group of patients were joined to the main group of research. At the same time, overall 20 patients were included in the third main group who is treated with IV drip infusion of O3 therapy and treatment of wounds with an ozonized odium chlorine solution, applications with ozonized olive oil. 


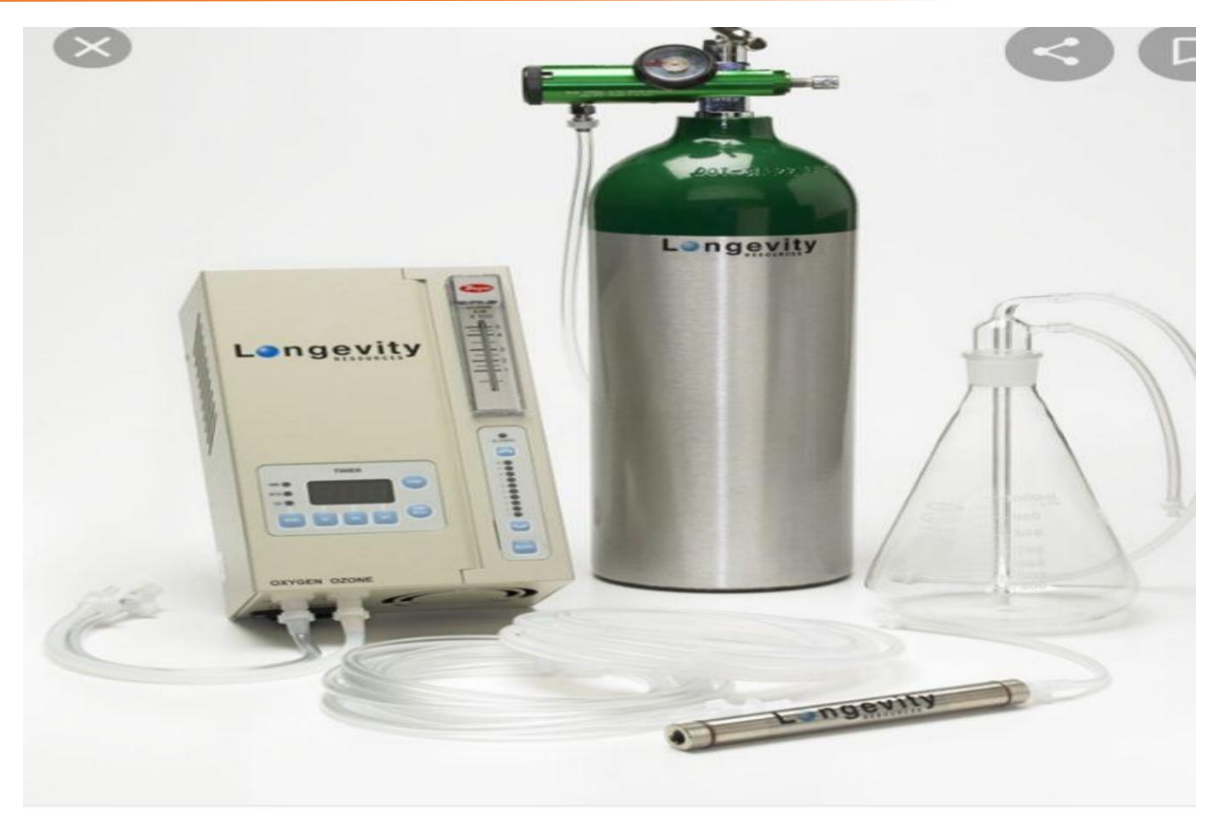

Figure.2: EXT 120 Ozone Generator Longevity

The medical device EXT120 Ozone Generator Longevity has been used to produce $\mathrm{O}_{3}$ gas and this gas is added to $\mathrm{NaCe}$ solution ozonated olive oil has been produced. The process of treatment commenced as injure takes place immediately and repeated at the same time of the day with the same dosage to clarify the efficacy of the ozone for the treatment of the soft tissue wounds of the maxillofacial injuries

The samples of the tissue from the wound edges were collected with the size of $5 \mathrm{~mm}$ 2,4 and 8 days of the treatment. Morphophysiological, histological along immunohistochemical investigations have been done from these wounds Patients with immunodeficiency, tobacco smokers, pregnant ones, and individuals with coagulopathies were not included in the investigation.

To control the wound healing period of the maxillofacial injuries special camera is used [13-18]. The monitoring of the wound started from the 2,4 and 8 days as maxillofacial soft tissue is injured. All the taken pictures compared with 2 days of the injure to monitor the wound healing process. A special computer program is used to measure wound sizes and compare pictures to clarify the healing process step by step. 


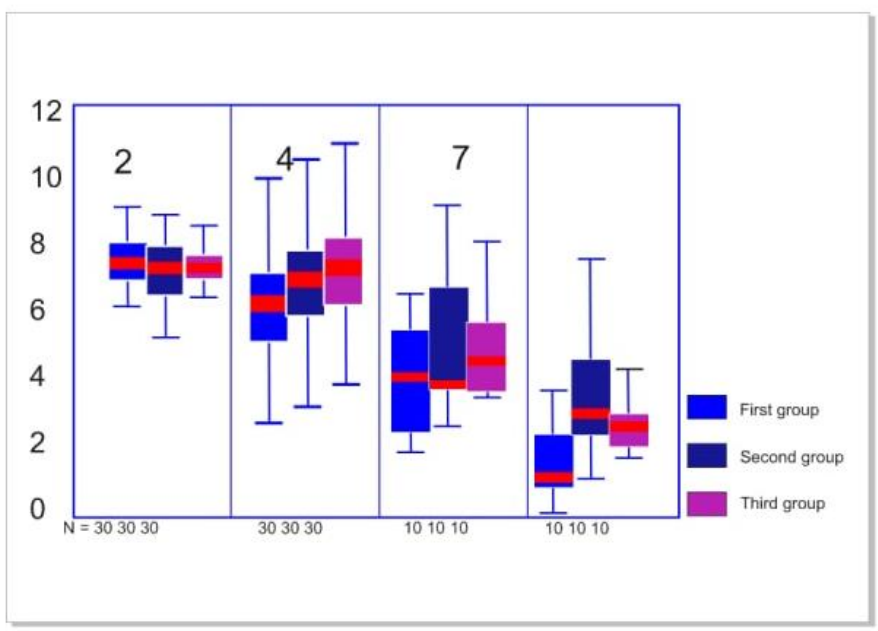

Figure.3: Measure of wound sizes in $\mathrm{mm} 2$ from 2 until 10 days including a number of marked injuries.

The regeneration process of the surface of the soft tissue wound monitored by morphological examinations. Wound's coverage with epithelial cells followed every 2 days and samples were taken for the assessment wound healing process. At the same time, freshly appeared epithelium mitosis is also detected during the following stage of monitoring.

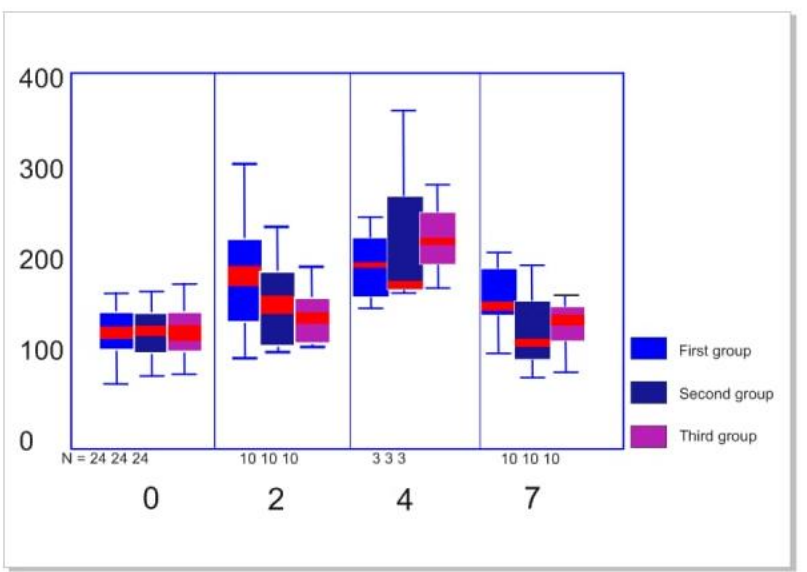

Figure.4: The proportion of assessed cells on the wounds examined, days and ways of treatment.

\section{RESULTS}

Regarding the results of the research, this was clear that ozonized $\mathrm{NaCe} 0,9 \%$ solution with
1600-1800 g/l concentration seems to be sufficient antibacterial power comparing to 
traditional chlorhexidine. So, the healing process of the soft tissue wound of the maxillofacial region within the main group exceeded the 2 remaining controlled groups of patients. In addition to this, this newly invented method of treatment with ozone showed that IV infusion ozonized norm saline together with cleaning wound surface with ozone water and application ozone olive oil to the soft tissue wounds is much more clinically effective. As a result of these participants reported positive changes in their wellbeing, good mood, objective and subjective features.
Patients complained of no temperature and their general conditions also improved due to the use of ozone. Furthermore, statistical dates demonstrated those patients in the controlled group with traditional methods of treatment smaller changes in the wound sizes rather than two main groups. Regarding the results of the investigation, this was clear that 9 out of 10 patients wound in the maxillofacial region covered with epithelium in the 8th day, where's just 5 out of 10 wounds surfaces covered with epithelium.

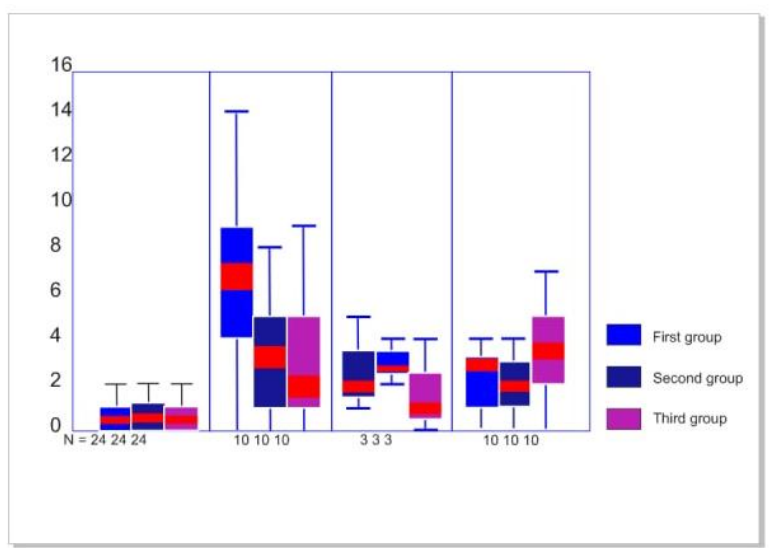

Figure.5: Cells under the division mitosis in the inspected line of investigation among 3 groups of treatment.

This information shows the positive effect of ozone therapy rather than traditional treatment with chlorhexidine bigluconate. The healing period of the wounds of the maxillofacial region accelerated due to IV admission of the ozonated sodium chloride solution and application of soft tissue wounds with ozone olive oil along with cleaning this ozonized water. Assessment of the effectiveness of the dry ozone-oxygen mixture to the wound with its IV admission showed that the second method proved to be very effective. So, it becomes clear that injured tissues received even more $\mathrm{O}_{2}$ extra application of ozonized olive oil. As a result of this, during the wound healing period, defensive cells phagocytic function improved, the proliferation of epithelial cells accelerated. Furthermore, fibroblast cells activation and collagen production of the wound surface improved with the use of ozone as a new approach to treatment.

\section{CONCLUSION}

The use of ozone for the soft tissue wounds of the maxillofacial injuries is much more effective rather than other remaining traditional treatment options. Individuals who are under the intravenous infusion ozonized norma saline. Patients that received an intravenous drip infusion of ozonized saline solution, wounds cleaned with ozonated sodium chlorine, and application ozone olive 
oil decreased the time of treatment noticeably, therefore the epithelialization process is also commenced early.

\section{REFERENCES}

1. Abdurakhmonov, F., Rizayev, J., Boymurodov, S., Ibragimov, D., Kholboev, S., \& Usmonov, R. (2021). Assessment of the Results for the Treatment of the Combined Soft Tissue Wounds with Ozone in the Maxillofacial Region. Annals of the Romanian Society for Cell Biology, 177183.

2. Alimova D.M., Kamilov H.P., Shukurova U.A. (2010). Clinical and immunological substantiation of the use of ozone therapy in the complex treatment of recurrent aphthous stomatitis. Uzbekiston Tibbiet journals. Toshkent. No.1. pp.41-43.

3. Boymurodov Sh.A. (2012). Improvement of diagnostics and treatment of patients with combined injuries of the bones of the facial skeleton. Diss. doc. honey. Science. Tashkent. pp. 22-24.

4. Shomurodov. K.E. (2010). Features of cytokine balance in gingival fluid at odontogenicphlegmon of the maxillofacial area. Doctor-aspirant. 42(5.1). pp.187-192.

5. Tillyashaykhov M. N., Rakhimov N. M. Khasanov Sh. T. (2019). Features of Clinical Manifestation of the bladder cancer in young people. Doctor Bulletin. Samarkand. №2. pp. 108-113.

6. Ilkhomovna, K. M., Eriyigitovich, I. S., \& Kadyrovich, K. N. (2020). Morphological Features of Microvascular Tissue Of The Brain At Hemorrhagic Stroke. The American Journal of Medical Sciences and Pharmaceutical Research, 2(10), 53-59.
7. Abdurakhmonov, F., Rizayev, J., Boymurodov, S., Ibragimov, D., Kholboev, S., \& Usmonov, R. (2021). Assessment of the Results for the Treatment of the Combined Soft Tissue Wounds with Ozone in the Maxillofacial Region. Annals of the Romanian Society for Cell Biology, 177183.

8. Karimov H.Ya., Shevchenko L.I., Boboev K.T., Yugai M.A. (2011). Method of ozone therapy Succinasol. Method. manual for doctors. Tashkent. 5-10, pp. 14-19.

9. Rizaev J.A., Boymuradov Sh.A., Abduraxmonov F.R., Gaffarov U.B. (2000). The role of ozone therapy in the treatment of open wounds in facial and maxillofacial joint injuries. Journal of Biology and Medical Problems. Samarkand. № 4. pp 230235.

10. E Gaybullaev, J Rizaev, Sh Alovitdinov, E Dusmukhamedov. (2020). Valuation of a retrospective analysis of the surgical treatment of inflammatory and dystrophic periodontal lesions according to the department of surgical dentistry TSDI. World journal of pharmaceutical and medical research.

11. Gopalakrishnan S., Parthiban S. (2012). Ozone- a new revolution in dentistry. J Bio Innova. 1:58-69.

12. K.E. Shomurodov. (2020). Comparative evaluation of the anatomical and functional state of the Journal of research in health science.

13. Rizaev, J., Khasanova, L., \& Fattakhov, R. (2020). The dental status of dentists with burnout syndrome. Journal of Critical Reviews, 7(12), 512-514.

14. Rizaev, J. A. (2011). Ecological pollutants in industrial areas of Uzbekistan: their influence on the 
The American Journal of Medical Sciences and Pharmaceutical Research

(ISSN - 2689-1026)

Published: June 28, 2021 | Pages: 75-81

IMPACT FACTOR

2021: 5.64

Doi: https://doi.org/10.37547/TAJMSPR/Volume03Issue06-12

OCLC - 1121105510

development of dental diseases. EuroAsian Journal of BioMedicine, Japan, 4(5), 12.

15. Hinz, B., Phan, S. H., Thannickal, V. J., Galli, A., Bochaton-Piallat, M. L., \& Gabbiani, G. (2007). The myofibroblast: one function, multiple origins. The American journal of pathology, 170(6), 1807-1816.

16. Das S. (2011). Application of ozone therapy in dentistry. Indian J Dent Adv. 3:538-42.
17. Maiya A. (2011). Applications of ozone in dentistry. Int J Clin Dent Sci. (2). pp.23-7.

18. Seidler $V$, Linetskiy I, Hubálková $H$, Staňková H, Šmucler R, Mazánek J. (2012). Ozone and its usage in general medicine and dentistry. A review articles. Prague Med Rep. 109(5). pp.130. 